$1-1-1993$

\title{
Hydrodynamical Modeling of a Multiple-Inlet Estuary/Barrier System: Insight Into Tidal Inlet Formation and Stability
}

\author{
Carl T. Friedrichs \\ Virginia Institute of Marine Science
}

David G. Aubrey

Graham S. Giese

Paul E. Speer

Follow this and additional works at: https://scholarworks.wm.edu/vimsbooks

Part of the Oceanography Commons

\section{Recommended Citation}

Friedrichs, Carl T.; Aubrey, David G.; Giese, Graham S.; and Speer, Paul E., "Hydrodynamical Modeling of a Multiple-Inlet Estuary/Barrier System: Insight Into Tidal Inlet Formation and Stability" (1993). VIMS Books and Book Chapters. 34.

https://scholarworks.wm.edu/vimsbooks/34

This Book Chapter is brought to you for free and open access by the Virginia Institute of Marine Science at W\&M ScholarWorks. It has been accepted for inclusion in VIMS Books and Book Chapters by an authorized administrator of W\&M ScholarWorks. For more information, please contact scholarworks@wm.edu. 


\title{
3
}

\section{Hydrodynamical Modeling of a Multiple-Inlet Estuary/Barrier System: Insight into Tidal Inlet Formation and Stability}

Carl T. Friedrichs, David G. Aubrey, Graham S. Giese and Paul E. Speer

\begin{abstract}
Two specific questions are addressed concerning the role of tidal hydrodynamics in determining the long-term morphologic evolution of the Nauset Beach-Monomoy Island barrier system and the Chatham Harbor-Pleasant Bay tidal estuary, Massachusetts: (1) why do the barrier and estuary exhibit a long-term $(\sim 150 \mathrm{yr})$ cycle of new inlet formation, and (2) once a new inlet forms, why is the resulting multiple inlet system unstable? To address these questions, a branched 1-d numerical model is used to recreate the basic flow patterns in the tidal estuary at ten-year intervals during the last half century and also to recreate flow conditions shortly before and shortly after the formation of the new inlet. Results suggest that an inlet will form through Nauset Beach once southerly elongation of the barrier has led to a critical head across the barrier at high tide. If this critical head (enhanced by storm surge and wave set-up) exists at high tide during consecutive tidal cycles, flood currents can deepen the overwash channel sufficiently to enable the stronger ebb currents to complete the formation process. Once a new inlet has formed, the surface gradient and tidal discharge are drastically reduced along the preexisting channel to the south of the inlet. This reduction eliminates the tidal
\end{abstract}


scouring action needed to keep the channel open. Rapid shoaling within the channel to the south of the new inlet completes the hydrodynamic decoupling of the northern and southern sections of the estuary.

\section{Introduction}

Tidal inlets between barrier spits and/or barrier islands change continually. Unless restricted by engineering structures or by naturally occurring obstacles such as resistant subsurface lithologies (FitzGerald and FitzGerald, 1977), they commonly migrate alongshore, frequently - but not always - in a downdrift direction (Aubrey and Speer, 1984). During severe storms accompanied by unusually high sea levels and waves attacking the outer barrier, new inlets may form and pre-existing inlets may close. Under most circumstances the general form and structure of the barrier through which the inlets pass remain intact despite such changes in the inlets themselves. However, an entirely different situation can be found in cases involving inlets situated at the downdrift end of barrier systems. Here, the barrier spit or island itself may

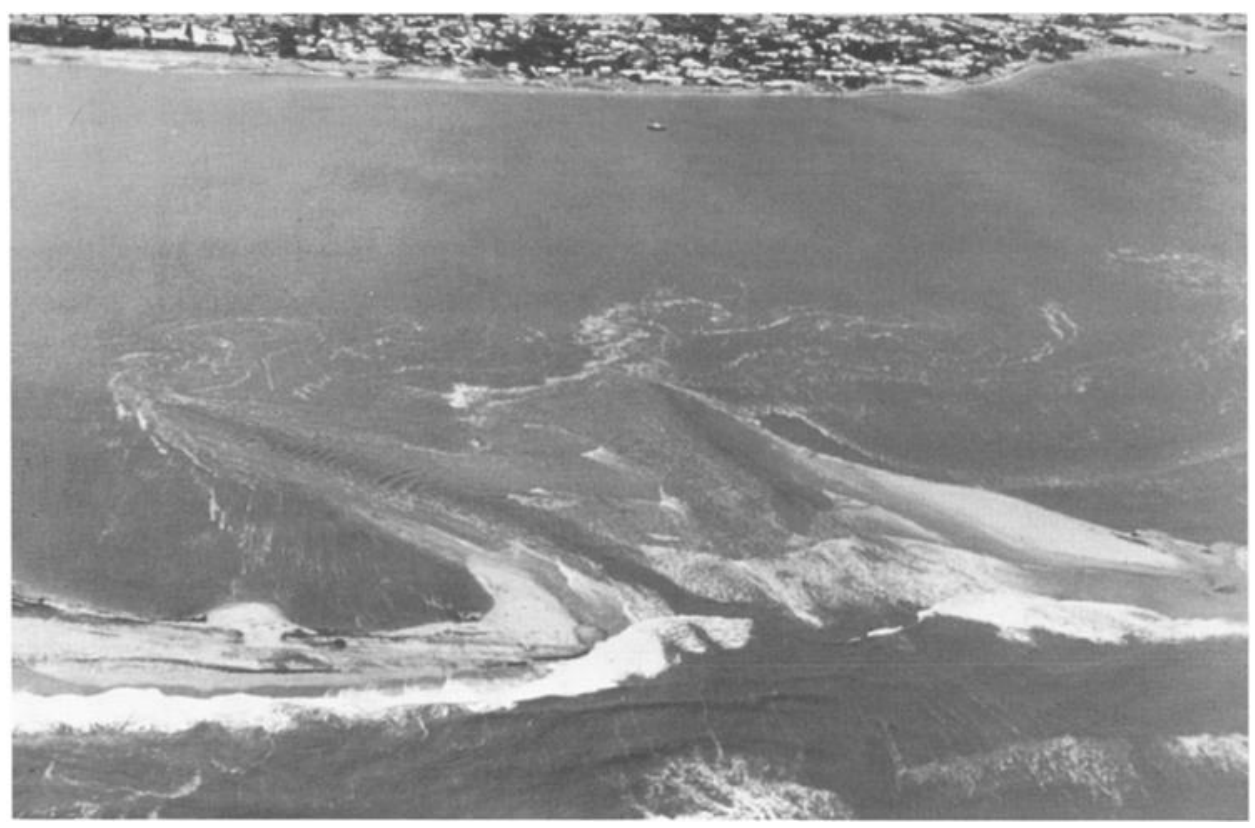

Figure 1. Aerial photograph of New Inlet on 3 January 1987 one day after its formation during a severe easterly storm with perigcan spring high tides. The distance across the breach at this time was on the order of 100 meters. By 1991, the inlet width exceeded $2 \mathrm{~km}$. 
become unstable, and drastic changes in barrier form may be triggered by changes in associated tidal inlets. A particularly clear example of the role of such "terminal" inlets is provided by the relationship between New Inlet in Chatham, Massachusetts (Fig. 1) and the patterns of change exhibited by the Nauset Beach-Monomoy Island barrier system.

A striking feature of this barrier system is its long period (150 yr) cycle of change (Fig. 2). In its simplest form, the system consists of two unbroken barriers, Nauset Beach and Monomoy Island, and all tidal flow between the ocean and the Chatham Harbor-Pleasant Bay estuary passes through a single tidal inlet (South Inlet) located immediately south of Nauset Beach (Fig. 2, c.1920, c.1940). However, as littoral drifting causes Nauset Beach to elongate to the south, Monomoy Island separates from Morris Island and a second inlet (West Inlet) is created (Fig. 2, c.1960, c.1980). Later, after continued southward growth, Nauset Beach is breached, forming a third inlet (New Inlet - Fig. 2, c.1990; Fig. 3). Following this event, the separated south end of Nauset Beach migrates onto shore, infilling the old tidal channel (Middle Channel) in the process. Eventually the migrating sand mass reconnects Monomoy Island to Morris Island and recreates the initial configuration.

The cyclical behavior of this barrier system has been discussed frequently (e.g., Mitchell, 1874; U.S. Army Corps of Engineers, 1968; Oldale et al., 1971; Goldsmith, 1972; McClennen, 1979; Aubrey, 1986; Leatherman and

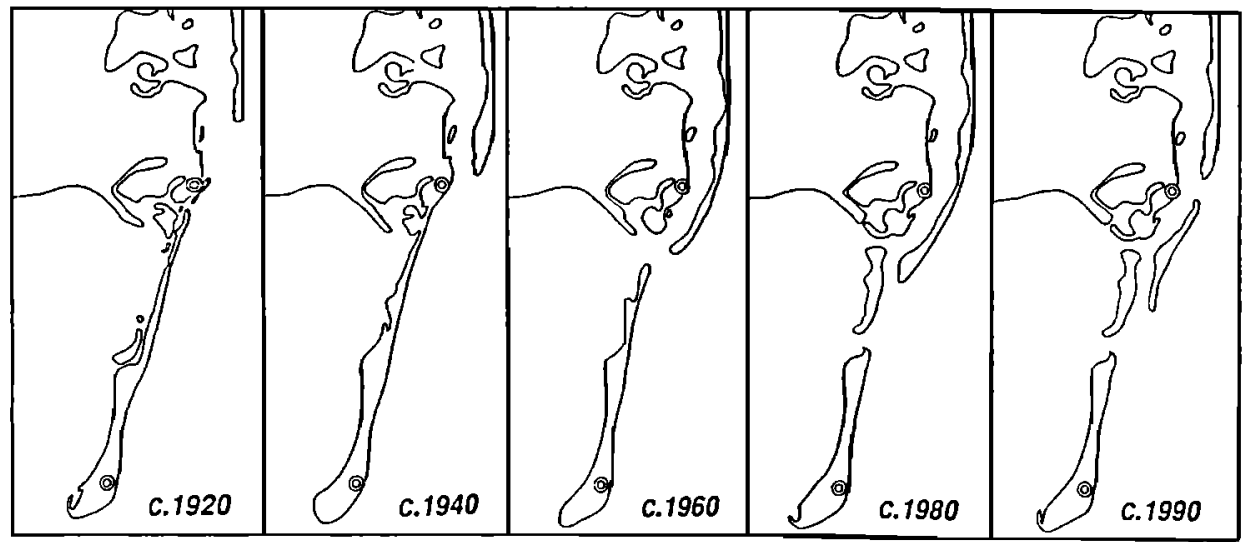

Figure 2. Historical Changes in the Nauset Beach-Monomoy Island barrier system during the most recent barrier growth cycle (after Giese, 1988). The sites of the Chatham and Monomoy Lighthouses are indicated. 
Zaremba, 1986; Giese, 1978, 1988; Liu et al., this volume). In this paper we address two specific questions regarding the role of tidal hydrodynamics in the evolution of the Nauset Beach-Monomoy Island barrier system and the Chatham Harbor-Pleasant Bay tidal estuary: (1) why do the barrier system
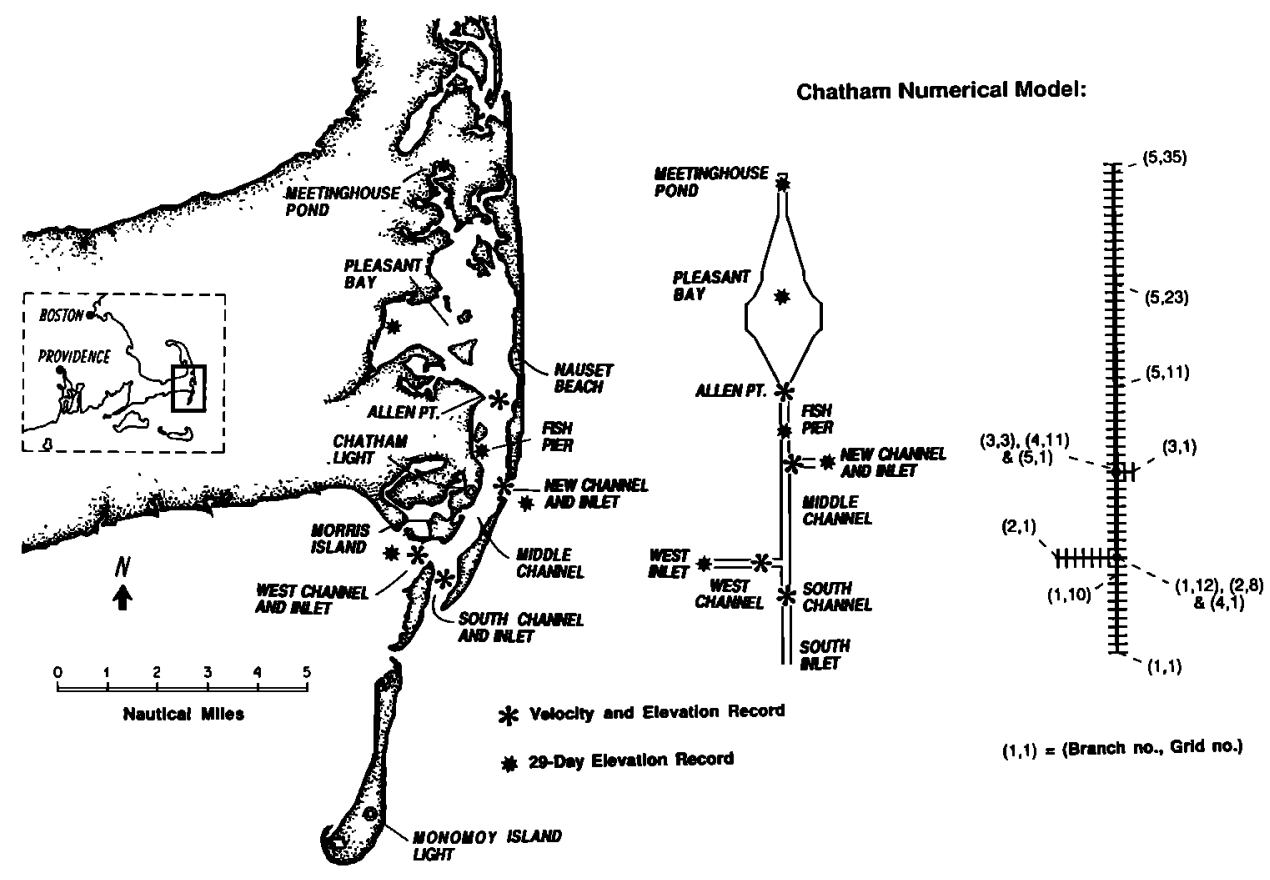

$(1,1)=$ (Branch no., Grid no.)

Figure 3. The Nauset Beach-Monomoy Island barrier system and Chatham Harbor-Pleasant Bay estuary under 1988 conditions with the locations of pressure sensors and current meters which recorded the data presented in Table 1. Also shown is a schematic layout of the one-dimensional, branched numerical model with corresponding sampling locations and a line-drawing of the model indicating the branch and grid numbering scheme. 
and tidal estuary exhibit this long-term cycle of new inlet formation, and (2) once a new inlet forms, why does Middle Channel become unstable, resulting in the decoupling of the northern and southern sections of the estuary?

The following section describes the numerical modeling techniques used in this study. The next section describes the tidal data used to force the model and compares observed and modeled tidal elevations and velocities from throughout the system. In the final two sections we use the model to examine specifically the cyclical behavior of barrier breaching and the stability of the multiple-inlet system following barrier breaching.

\section{Model Formulation}

For this study we adapted an existing one-dimensional nonlinear tidal propagation model for use in a multiple inlet system. Earlier versions have been applied successfully to single inlet, single channel applications (Speer and Aubrey, 1985; Friedrichs and Aubrey, 1988) and to branched channel applications (Friedrichs and Aubrey, 1989; Giese et al., 1989b). The model is based on the cross-sectionally integrated equations of motion:

$$
b \frac{\partial \zeta}{\partial t}+\frac{\partial Q}{\partial x}=0, \quad \frac{\partial Q}{\partial t}+\frac{\partial}{\partial x} \frac{Q^{2}}{A}=-g A \frac{\partial \zeta}{\partial x}-c_{d} \frac{Q}{A}\left|\frac{Q}{A}\right| P
$$

where $b=$ channel width, $\zeta=$ water surface elevation, $Q=$ volume transport, $A=$ channel cross-sectional area, $g=$ acceleration of gravity, $c_{d}=$ drag coefficient, and $P=$ wetted channel perimeter. The above representation of estuarine physics assumes estuary length $\gg$ width, width $\gg$ depth, a wellmixed water-column, and negligible fresh-water inflow.

To solve the above equations, continuous derivatives were replaced by centered differences in space and forward differences in time:

$$
b_{j} \frac{\zeta_{j}^{n+1}-\zeta_{j}^{n}}{\Delta t}+\frac{Q_{j+1}^{n}-Q_{j-1}^{n}}{2 \Delta x}=0
$$




$$
\begin{gathered}
\frac{Q_{j}^{n+1}-Q_{j}^{n}}{\Delta t}+\frac{1}{2 \Delta x}\left(\frac{\left(Q_{j+1}^{n}\right)^{2}}{A_{j+1}^{n}}-\frac{\left(Q_{j-1}^{n}\right)^{2}}{A_{j-1}^{n}}\right)= \\
-g A_{j}^{n+1} \frac{\zeta_{j+1}^{n+l}-\zeta_{j-1}^{n+1}}{2 \Delta x}-c_{d} \frac{Q_{j}^{n}}{A_{j}^{n}}\left|\frac{Q_{j}^{n}}{A_{j}^{n}}\right| P_{j}^{n} .
\end{gathered}
$$

where $\Delta t$ and $\Delta x$ indicate the time and space step sizes, subscript $j$ indicates grid number, and superscript $n$ indicates time step number. At each new time step, (1) was solved first for sea surface elevation, $\zeta_{,}^{n+1}$. Then (2) was solved for transport, $Q_{j}^{n+1} . A_{j}^{n}$ and $P_{j}^{n}$ were found as simple functions of sea surface elevation. The form of the advective term used in this numerical scheme can cause numerical instability under certain circumstances. In this application, however, dissipation through the friction term overcame any tendency towards advective instability.

The model is composed of one-dimensional branches which connect at nodes (Fig. 3). The model was forced by prescribed, periodic time series of elevation at each inlet, and a no flow condition was applied at inland boundaries. Two matching conditions were applied at each node: continuity of transport $\left(Q_{1}+Q_{2}+Q_{3}=0\right)$ and continuity of elevation $\left(\zeta_{1}=\zeta_{2}=\zeta_{3}\right)$. At the inlets, inland boundaries and nodes, centered differences in space were replaced by either forward or backward differences (i.e., $j+1$ or $j-1$ was replaced by $j$, and $2 \Delta x$ was replaced by $\Delta x$ ), as appropriate. Throughout this study we used $\Delta t=15$ seconds, $\Delta x=250$ meters, and $c_{d}=0.02$, scales previously found to be appropriate for shallow, frictionally-dominated tidal embayments (Speer and Aubrey, 1985; Friedrichs and Madsen, 1992).

The numerical modeling performed in this study was diagnostic in nature rather than predictive. Our aim was to determine which aspects of the barrier and estuary geometry control the fundamental hydrodynamic patterns and therefore most strongly influence patterns of morphologic evolution. Our aim was not to reproduce exactly observed time series of tidal elevation and/or velocity. Therefore, to isolate the geometric features of interest, we chose to model the tidal estuary simply, using constant depth, rectangular channels. 
We chose a uniform depth of 2.5 meters (relative to mean sea level at the inlets), which is approximately the average depth of the Chatham HarborPleasant Bay estuary. We also chose a constant channel width of 300 meters throughout the embayment, except in the immediate vicinity of Pleasant Bay, where the model width increased to 2000 meters (Fig. 3). The model was not "tuned" in any way.

\section{Comparison with Field Data}

Field data were collected as part of a larger observational study which investigated the overall morphological response of the barrier system to the formation of New Inlet (Giese et al., 1989a; Liu et al., this volume), and data acquisition methods are described in greater detail elsewhere. Synoptic observations of tidal elevation in April and May 1988 were provided by five temperature and depth recorders (TDRs) deployed at locations indicated in Figure 3 and Table 1. Additional elevation data were provided by a TDR deployment in Pleasant Bay in September 1988. During April and May, 1988, current meters, which also recorded tidal elevation, were deployed at four additional locations (Fig. 3, Table 1). Because of equipment limitations, the current measurements could not be synoptic (Giese et al., 1989a). Elevation set-up could not be estimated from field data because of inadequate surveying between instruments.

To approximate the mean conditions observed in the field, model elevations were forced at both South Inlet and New Inlet using the $M_{2}$ and $M_{4}$ tidal components observed offshore of New Inlet in April 1988 (Table 1). West Inlet, which faces Nantucket Sound, was forced with the $\mathrm{M}_{2}$ and $\mathrm{M}_{4}$ components observed offshore of West Inlet (Table 1). A visual comparison of field observations and numerical model results (Fig. 4) indicates that the simple numerical model captured the fundamental hydrodynamic behavior of the tidal estuary. For 1988 conditions, both model results and observations indicate a progressive wave relation between elevation and velocity at Allen Point, a standing wave relation in West Channel, and an intermediate relation in New Channel. The modeled and observed elevation-velocity relation in South Channel (not shown) are also consistent and similar to the intermediate 
relation in New Channel. A quantitative comparison of numerical results and observations for 1988 conditions is presented in Table 1.

The observed and modeled $\mathrm{M}_{2}$ elevations agree well throughout almost all of the system. The elevation observations collected by pressure sensors de-

Table 1.

Elevations: observed and modeled (in parentheses)

\begin{tabular}{|c|c|c|c|c|c|c|c|}
\hline $\begin{array}{l}\text { gauge or } \\
\text { branch, grid }\end{array}$ & starting date & $\begin{array}{l}\text { duration } \\
\text { in hours }\end{array}$ & $\begin{array}{l}\mathrm{M}_{2} \text { amp. } \\
\text { in } \mathrm{cm}\end{array}$ & $\begin{array}{c}\mathrm{M}_{2} \text { lag } \\
\text { in deg }\end{array}$ & $\begin{array}{c}\mathrm{M}_{4} / \mathrm{M}_{2} \\
\text { amp. ratio }\end{array}$ & $\begin{array}{c}2 \mathrm{M}_{2}-\mathrm{M}_{4} \\
\text { phase in deg }\end{array}$ & $\begin{array}{l}\text { mean elev. } \\
\text { in } \mathrm{cm}\end{array}$ \\
\hline $\begin{array}{l}\text { West Inlet } \\
\qquad(2,1)\end{array}$ & 5 Apr. ${ }^{\prime} 88$ & 697 & $\begin{array}{c}56 \\
(56)\end{array}$ & $\begin{array}{c}8 \\
(8)\end{array}$ & $\begin{array}{c}0.086 \\
(0.086)\end{array}$ & $\begin{array}{c}252 \\
(252)\end{array}$ & $\begin{array}{l}\text { n.a. } \\
(0)\end{array}$ \\
\hline $\begin{array}{c}\text { West Channel } \\
(2,6)\end{array}$ & 6 Apr. '88 & 73 & $\begin{array}{c}73 \\
(74)\end{array}$ & $\begin{array}{l}\text { n.a. } \\
(8)\end{array}$ & $\begin{array}{c}0.025 \\
(0.030)\end{array}$ & $\begin{array}{c}349 \\
(336)\end{array}$ & $\begin{array}{l}\text { n.a. } \\
(4)\end{array}$ \\
\hline $\begin{array}{c}\text { South Channel } \\
(1,10)\end{array}$ & 4 Apr. ' 88 & 73 & $\begin{array}{c}79 \\
(84)\end{array}$ & $\begin{array}{l}\text { n.a. } \\
(7)\end{array}$ & $\begin{array}{c}0.004 \\
(0.034)\end{array}$ & $\begin{array}{l}186 \\
(14)\end{array}$ & $\begin{array}{l}\text { n.a. } \\
(4)\end{array}$ \\
\hline $\begin{array}{c}\text { Ebb-tide delta } \\
(3,1)\end{array}$ & 5 Apr. 88 & 697 & $\begin{array}{c}105 \\
(105)\end{array}$ & $\begin{array}{c}0 \\
(0)\end{array}$ & $\begin{array}{c}0.025 \\
(0.025)\end{array}$ & $\begin{array}{c}285 \\
(285)\end{array}$ & $\begin{array}{l}\text { n.a. } \\
(0)\end{array}$ \\
\hline $\begin{array}{c}\text { New Channel } \\
(3,3)\end{array}$ & 21 Apr. '88 & 73 & $\begin{array}{c}80 \\
(83)\end{array}$ & $\begin{array}{l}31 \\
(8)\end{array}$ & $\begin{array}{c}0.033 \\
(0.045)\end{array}$ & $\begin{array}{c}29 \\
(19)\end{array}$ & $\begin{array}{l}\text { n.a. } \\
(6)\end{array}$ \\
\hline $\begin{array}{c}\text { Fish Pier } \\
(5,4)\end{array}$ & 5 Apr. ' 88 & 697 & $\begin{array}{c}66 \\
(68)\end{array}$ & $\begin{array}{c}35 \\
(21)\end{array}$ & $\begin{array}{c}0.052 \\
(0.066)\end{array}$ & $\begin{array}{c}75 \\
(37)\end{array}$ & $\begin{array}{l}\text { n.a. } \\
(10)\end{array}$ \\
\hline $\begin{array}{c}\text { Allen Point } \\
(5,10)\end{array}$ & 21 Apr. '88 & 232 & $\begin{array}{c}66 \\
(54)\end{array}$ & $\begin{array}{c}49 \\
(51)\end{array}$ & $\begin{array}{c}0.074 \\
(0.108)\end{array}$ & $\begin{array}{c}74 \\
(46)\end{array}$ & $\begin{array}{l}\text { n.a. } \\
\text { (13) }\end{array}$ \\
\hline $\begin{array}{c}\text { Pleasant Bay } \\
(5,23)\end{array}$ & 22 Sep. ' 88 & 697 & $\begin{array}{c}54 \\
(54)\end{array}$ & $\begin{array}{c}69 \\
(60)\end{array}$ & $\begin{array}{c}0.159 \\
(0.133)\end{array}$ & $\begin{array}{c}64 \\
(50)\end{array}$ & $\begin{array}{l}\text { n.a. } \\
\text { (13) }\end{array}$ \\
\hline $\begin{array}{l}\text { Meeting House } \\
\text { Pond }(5,35)\end{array}$ & 5 Apr. '88 & 697 & $\begin{array}{c}59 \\
(54)\end{array}$ & $\begin{array}{c}73 \\
(60)\end{array}$ & $\begin{array}{c}0.219 \\
(0.134)\end{array}$ & $\begin{array}{c}73 \\
(53)\end{array}$ & $\begin{array}{l}\text { n.a. } \\
\text { (13) }\end{array}$ \\
\hline
\end{tabular}

Along-channel velocities: observed and modeled (in parentheses)

\begin{tabular}{|c|c|c|c|c|c|c|c|}
\hline gauge & starting date & $\begin{array}{l}\text { duration } \\
\text { in hours }\end{array}$ & $\begin{array}{r}\mathrm{M}_{2} \text { amp } \\
\text { in } \mathrm{cm} / \mathrm{s}\end{array}$ & $\begin{array}{c}\text { elev.-vel. } \\
\text { phase in deg }\end{array}$ & $\begin{array}{c}\mathrm{M}_{4} / \mathrm{M}_{2} \\
\text { amp. ratio }\end{array}$ & $\begin{array}{c}2 \mathrm{M}_{2}-\mathrm{M}_{4} \\
\text { phase in deg }\end{array}$ & $\begin{array}{c}\text { mean vel } \\
\text { in } \mathrm{cm} / \mathrm{s}\end{array}$ \\
\hline $\begin{array}{l}\text { West Channel } \\
\qquad(2,6)\end{array}$ & 6 Apr. '88 & 73 & $\begin{array}{c}82 \\
(45)\end{array}$ & $\begin{array}{c}4 \\
(0)\end{array}$ & $\begin{array}{c}0.152 \\
(0.188)\end{array}$ & $\begin{array}{c}76 \\
(41)\end{array}$ & $\begin{array}{l}26 \\
(7)\end{array}$ \\
\hline $\begin{array}{c}\text { South Channel } \\
\qquad(1,10)\end{array}$ & 4 Apr. ' 88 & 73 & $\begin{array}{c}38 \\
(35)\end{array}$ & $\begin{array}{c}27 \\
(21)\end{array}$ & $\begin{array}{c}0.112 \\
(0.102)\end{array}$ & $\begin{array}{c}325 \\
(353)\end{array}$ & $\begin{array}{l}-3 \\
(1)\end{array}$ \\
\hline $\begin{array}{c}\text { New Channel } \\
(3,3)\end{array}$ & 21 Apr. '88 & 73 & $\begin{array}{l}106 \\
(78)\end{array}$ & $\begin{array}{c}38 \\
(37)\end{array}$ & $\begin{array}{c}0.098 \\
(0.118)\end{array}$ & $\begin{array}{c}267 \\
(340)\end{array}$ & $\begin{array}{l}-8 \\
(-3)\end{array}$ \\
\hline $\begin{array}{l}\text { Allen Point } \\
(5,10)\end{array}$ & 21 Apr. '88 & 73 & $\begin{array}{c}59 \\
(57)\end{array}$ & $\begin{array}{c}63 \\
(81)\end{array}$ & $\begin{array}{c}0.216 \\
(0.223)\end{array}$ & $\begin{array}{c}357 \\
(349)\end{array}$ & $\begin{array}{l}-16 \\
(-8)\end{array}$ \\
\hline
\end{tabular}


ployed with the current meters may not represent equilibrium conditions because their record lengths are relatively short. The observed and modeled $\mathrm{M}_{4}$ elevations and velocities are consistent in terms of both relative phase and amplitude, which indicates the numerical model also captured the fundamental nonlinear tidal processes occurring in the tidal estuary. The amplitudes of observed and modeled $\mathrm{M}_{2}$ velocities were expected to disagree to some degree for at least three reasons: (1) the short velocity records do not represent equilibrium flow conditions; (2) model results are cross-sectionally averaged velocities whereas observations are point velocities; and (3) the model did not attempt to represent the smaller scale expansions and contractions in crosssectional geometry. Nevertheless, the comparison of numerical and observational data presented in this section indicates that a relatively simple model captures the fundamental linear and nonlinear hydrodynamics observed at the tidal estuary in 1988.

Allen Point

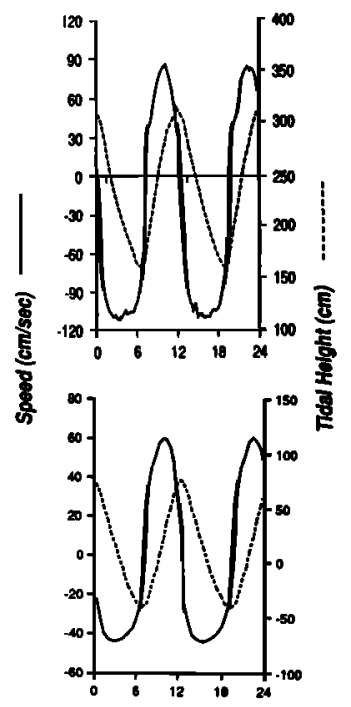

Elepsed Time (hrs.)
New Channel

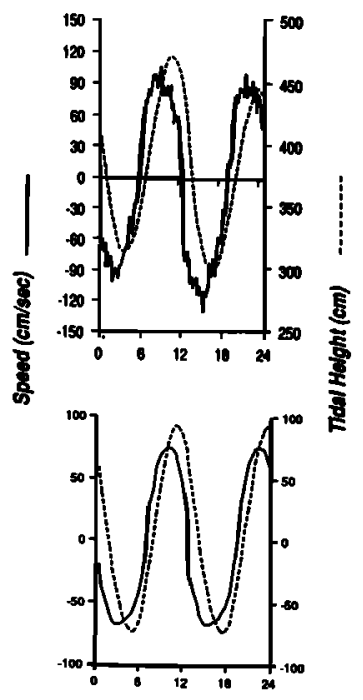

Elapsed Time (hrs.)
West Channel

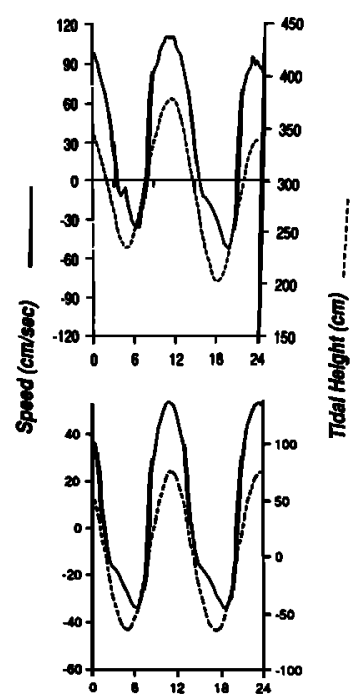

Elepsed The (hrs.)

Figure 4. Comparison of observed and modeled tidal clevations and along-channel velocities for three locations within the tidal estuary (see Figure 3). The upper three plots are observed records and the lower three plots are modeling results. Positive velocities are northward at Allen Point and westward at New Channel and West Channel. 


\section{Examination of Cyclical Behavior}

To investigate the role of tidal hydrodynamics in cyclical barrier breaching, we used the numerical model to recreate the basic flow patterns in the Chatham Harbor-Pleasant Bay estuary at ten-year intervals between 1936 and 1986 (first six configurations in Fig. 5). The historical geometries are based on previous studies of the morphologic evolution of the Nauset BeachMonomoy Island barrier system (Giese, 1978, 1988). During the first three ten-year periods (Fig. 5), the system had only one inlet, and the corresponding models were forced only by the Atlantic $M_{2}$ and $M_{4}$ tides (as observed off New Inlet in May 1988 - see Fig. 3). In 1958 a breach formed between Monomoy Island and the mainland, creating a second inlet into the estuary. Thus the next three models (Fig. 5) contain two inlets: West Inlet and South Inlet. For these three models, West Inlet was forced with the Nantucket Sound $M_{2}$ and $M_{4}$ tides (as observed off West Inlet in May 1988), whereas South Inlet was forced with the Atlantic tide.

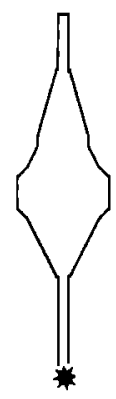

1936

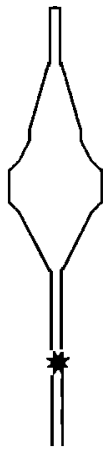

1946
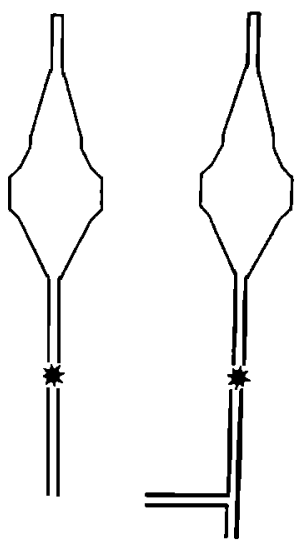

1966
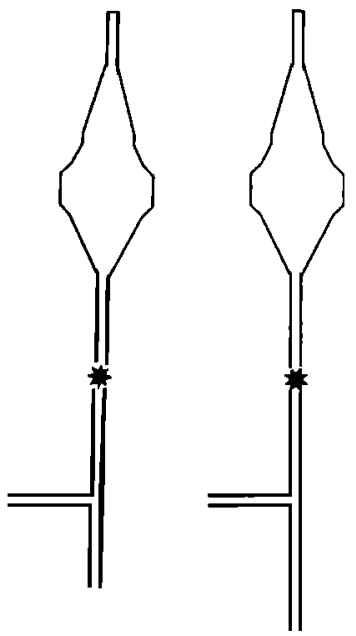

1986

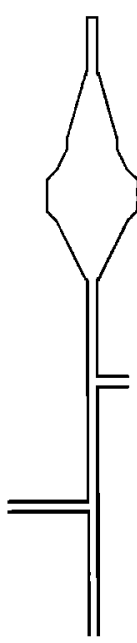

1988

Figure 5. Schematic layouts of numerical models representing the Chatham Harbor-Pleasant Bay estuary at various points during its evolulion, based on historical data summarized in Figure 1. Asterisks indicate the site of tidal elevation and tidal head calculations displayed in Figure 6. 
We examined the elevations produced by the six historical models at the site of the 1987 breach under mean tidal conditions (Fig. 6a). Tidal evolution is as might be expected, consisting of monotonically reduced tidal range, increasing phase lag, increasing mean water level set-up, and increasing tidal nonlinearity (larger $\mathrm{M}_{4} / \mathrm{M}_{2}$ ratio). From the modeled elevations, we calculated the maximum tidal head across the barrier around both ocean high and ocean low tide (Fig. 6b). Instantaneous tidal head across the barrier results from reduction in tidal range inside the barrier, longer phase lags, and mean water level set-up as the barrier elongates to the south. The results indicate that during most of the lengthening of Nauset Beach, the head across the barrier was significantly larger near ocean low tide than near ocean high tide. The ocean low tide head also developed more rapidly during the elongation of the barrier. According to model results, low tide head reached its peak prebreach value approximately twenty years before the breach occurred and remained relatively constant until the breach. High tide head, in contrast, continued to increase until the time of the breach.

(a) Harbor tide modeled at site of New Inlet

(b) Tidal head modeled at site of New Inlet
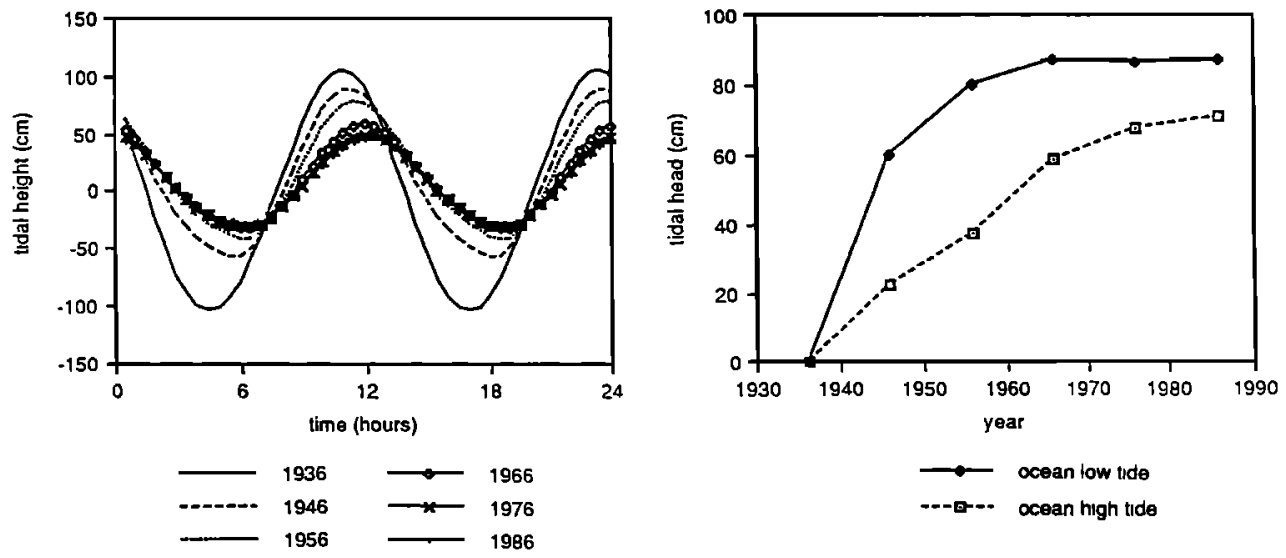

Figure 6. Model results at the future site of New Inlet for various stages during the evolution of the Chatham Harbor-Pleasant Bay Estuary: (a) tidal elevations within the estuary and (b) tidal head across the barrier. See Figure 5 for model configurations and sampling location. 
These results suggest that tidal inlet formation through Nauset Beach requires — in addition to the initiating storm wave overwash - critical tidal heads across the barrier at ocean high as well as ocean low tide. Nauset Beach has been subject to numerous washovers since the turn of the century, for example during the severe winter storm of 6 February 1978 which breached Monomoy Island. Yet these earlier washovers of Nauset Beach failed to develop into permanent inlets--even though the head across the barrier at low tide already may have attained its maximum pre-breach value. Our model results suggest that the initial stage of inlet formation, when the overwash channel is deepened by strong flood currents, is crucial to permanent inlet formation. Only if and when the channel becomes deeply scoured by strong flood currents, can the even stronger ebb currents complete the formation process.

Thus it appears that the time interval between episodes of inlet formation depends ultimately on the development of a critical ocean high tide head accompanied by adequate ocean low tide gradient. This critical head results from distortion of the tidal elevation signal within the estuary at the site of the potential inlet. At Chatham, the distortion develops in response to physical changes in the form of the barrier and estuary, specifically the elongation of Nauset Beach and the formation of West Channel.

The behavior of the incipient inlet during the early days of January, 1987, supports our hypothesis of a critical high tide head. The breaching began with an overwash channel produced at perigean spring high tide during a severe easterly storm. For the first several days following that initial breaching, the new channel - while presumably deepening with each successive flood tide - was not deep enough to permit appreciable ebb flow, and across-barrier sediment transport was largely westward (see Fig. 1). It appears that only after sufficient channel deepening had been produced by flood currents, were the ebbs - driven by even greater heads - able to complete formation of New Inlet.

Of course other factors contribute to the breaching. Storm surge is required to raise mean water level in both the ocean and lagoon, so that the barrier can be overwashed and the hydraulic link can be established. This initial superelevation appears critical to the process to allow the pressure gradients to work. In addition, wave set-up on the ocean side of the barrier acts to 
increase the sea-to-land gradient. Wave set-up of nearly one meter may accompany five meter waves, for example. Morphologic features may also facilitate the breaching process. A weakness (blow-out) in the barrier dunes due to previous overwashes may channelize water across the barrier during storms. The likelihood of breaching may be enhanced where the barrier has been narrowed by long-term beach erosion or where the bay immediately adjacent to the barrier is unusually deep. Finally, groundwater behavior within the barrier may also play a role (e.g., Ogden, 1974; Weidman et al., in prep.).

\section{Examination of Multiple-Inlet Stability}

In order to examine the stability of the multiple-inlet system following the formation of New Inlet, we applied our model to the 1986 and 1988 configurations of the system (last two diagrams in Fig. 5). A comparison of the model results indicates that formation of New Inlet altered the fundamental tidal flow pattern through much of the southern portion of the Chatham Harbor-Pleasant Bay estuary (Fig. 7). Through West Channel, for example, modeled discharge near low water reversed direction after the development of New Inlet and discharge near high water increased markedly. Yet the most drastic changes in modeled discharge after the formation of New Inlet occurred in Middle Channel. After the breach of Nauset Beach, discharge through Middle Channel reversed direction relative to pre-breach conditions and decreased dramatically in magnitude (Fig. 8). The large decrease in modeled discharge through Middle Channel was a direct result of a drastically reduced surface gradient (Fig. 7). Before the breach, the maximum change in surface elevation over the length of Middle Channel was 20 to $30 \mathrm{~cm}$. After the breach it was less than $10 \mathrm{~cm}$.

Thus we conclude that formation of New Inlet produced a condition of hydrodynamical instability within the multiple-inlet system, leading to decoupling of the previously existing inlets from northern Chatham Harbor and Pleasant Bay, and the establishment of New Inlet as the primary - and only stable - channel connecting them with the open sea. The practical importance of this result for harbor management is clear: new channels that developed following the formation of New Inlet have the potential of serving 
as reliable routes for navigation, but former channels that are now hydrodynamically inactive and shoaling, may not be reliable waterways and efforts to keep their entrances open through dredging may be ineffective.

Extreme shoaling at the northern end of Middle Channel is evident from aerial photography taken following the formation of New Inlet and is discussed elsewhere in this volume (e.g., Liu et al.). Prior to completion of this model study, it was thought by some that the observed shoaling might indicate that the extremely energetic sedimentation processes associated with wave action at New Inlet was responsible for overwhelming and altering the previously existing hydrodynamical system at the north end of Middle Channel. However, the present results indicate that the hydrodynamical changes resulted

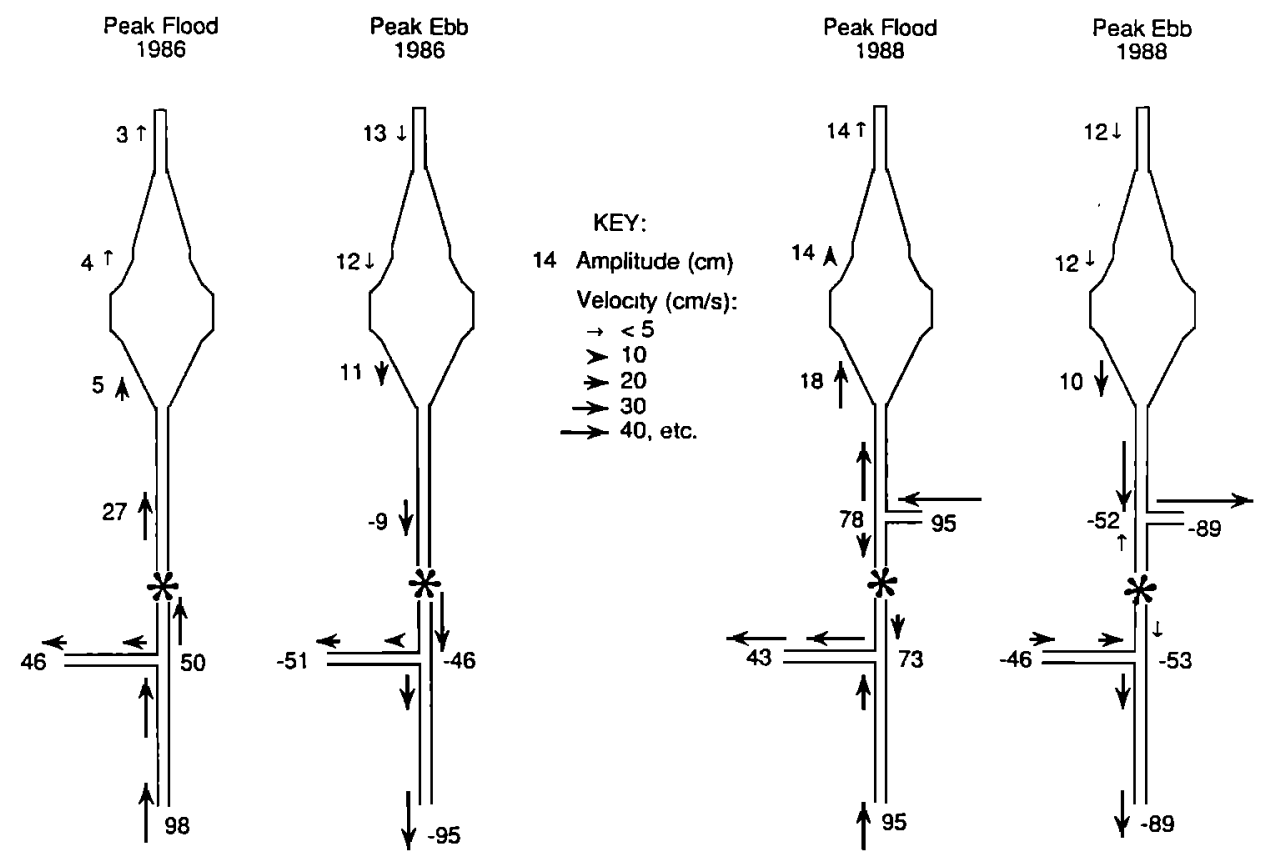

Figure 7. Model results for tidal elevation and vclocity before and after the formation of New Inlet. Values shown are concurrent with the time of peak cbb or peak flood at the site of New Inlet. Also indicated is the site of tidal velocity measurements displayed in Figure 8. 


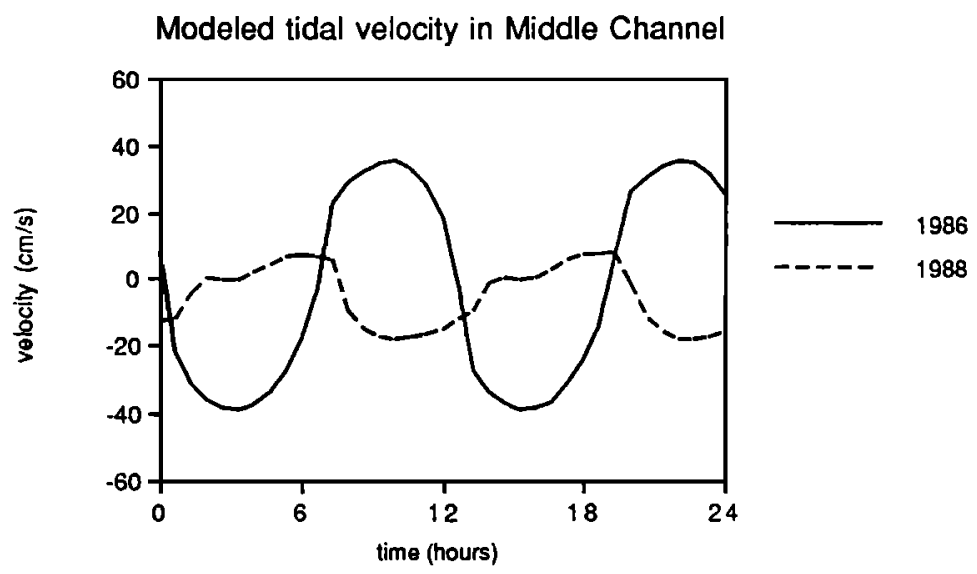

Figure 8. Model tidal velocities within Middle Channel before and after the formation of New Inlet. Positive velocities are northward. See Figure 7 for model configurations and sampling location.

primarily from the reduced Chatham Harbor-Pleasant Bay surface gradient produced by the opening of New Inlet, and that the shoaling of the northern and southern ends of Middle Channel is primarily the result, rather than the cause, of the altered hydrodynamics.

\section{Summary}

This paper addresses two specific questions concerning the role of tidal hydrodynamics in determining the long-term morphologic evolution of the Nauset Beach-Monomoy Island barrier system and the Chatham HarborPleasant Bay tidal estuary: (1) why do the barrier system and tidal estuary exhibit a long-term cycle of new inlet formation, and (2) once a new inlet forms, why does the channel to the south of the inlet become unstable, resulting in the decoupling of the northern and southern sections of the estuary?

To answer these questions, we adapted an existing one-dimensional finite difference model for use in a multiple inlet system. Comparison to field observations indicates that a relatively simple model captures the fundamental linear and nonlinear hydrodynamics observed throughout the Chatham Harbor-Pleasant Bay estuary in 1988, approximately 15 months after the breach occurred. 
To address question (1) specifically, the numerical model was used to recreate the basic flow patterns in the tidal estuary at ten-year intervals during the last half century. Modeling results suggest that an inlet will form through Nauset Beach when southerly elongation of the barrier has led to a critical shoredirected head across the barrier at ocean high tide. Only if a critical head exists at high tide during consecutive tidal cycles can flood currents deepen the overwash channel sufficiently to enable the stronger ebb currents to complete the formation process. Other factors, such as storm surge, wave set-up, preexisting barrier geometry, and perhaps ground water behavior, can contribute to the breaching.

To address question (2), the model was used to compare the flow conditions in 1986 and 1988, shortly before and shortly after the formation of the new inlet. Model results indicate that formation of the inlet drastically reduces the surface gradient along the pre-existing channel to the south of the inlet. The reduced surface gradient in turn reduces the discharge and velocity through the channel, eliminating the tidal scouring action needed to keep the channel entrances open. The observed accumulation of sand marks the final phase of tidal decoupling.

Model trends suggest the inlet formation potential at other sites may be described by similar studies. Other areas of Cape Cod, such as Nauset Inlet to the north and Popponesset Inlet at Mashpee, experience barrier spit elongation and hence changes in tidal properties within embayments served by inlets.

\section{Acknowledgments}

This work is the result of research sponsored by NOAA National Sea Grant College Program Office, Department of Commerce, under Grant No. NA88AA-D-SG090, Woods Hole Oceanographic Institution Sea Grant Project No. R/O-6. The U.S. Government is authorized to produce and distribute reprints for governmental purposes notwithstanding any copyright notation that may appear hereon. Support for this work also was provided by the U.S. Army Corps of Engineers (New England Division), the Town of Chatham, and the W.H.O.I. Coastal Research Center. Woods Hole Oceanographic Institution Contribution No. 8317. 


\section{References}

Aubrey, D. G., 1986. A study of bluff erosion at Morris Island, Chatham, MA. Aubrey Consulting, Inc., A report submitted to local residents, Falmouth, MA, 55 p. + appendices.

Aubrey, D. G., and P. E. Speer, 1984. Updrift migration of tidal inlets. Journal of Geology, v. 92, p. 531-545.

FitzGerald, D. M., and S. A. FitzGcrald, 1977. Factors influencing tidal inlet throat geometry. In: Coastal Sediments 1977. American Society ofCivil Engineers, New York, p. 563-581.

Friedrichs, C. T., and D. G. Aubrey, 1988. Non-linear tidal distortion in shallow well-mixcd estuaries: a synthesis. Estuarine, Coastal and Shelf Science, v. 27:, p. 521-545.

Friedrichs, C. T., and D. G. Aubrey, 1989. Numerical modeling of Nauset Inlet/Marsh. In: C. T. Roman and K. W. Able (eds.), An ecological analysis of Nauset Marsh, Center for Coastal and Environmental Studies, Rutgers - The State University of New Jersey, New Brunswick, NJ, Appendix D, p. A179-A222.

Friedrichs, C. T., and O. S. Madsen, 1992. Nonlinear diffusion of the tidal signal in frictionally dominated embayments. Journal of Geophysical Research, v. 97, p. 56375650.

Giese, G. S., 1978. The barricr beaches of Chatham, Massachusetts. Provincetown Center for Coastal Studies, April 1978 Report, Provincetown, MA, 7 pp.

Giese, G. S., 1988. Cyclical behavior of the tidal inlet at Nauset Beach, Chatham, Massachusetts. In: D. G. Aubrey and L. Weishar (eds.), Hydrodynamics and Sediment Dynamics of Tidal Inlets, Lecture Notes on Coastal and Estuarine Studies, v. 29, Springer-Verlag, New York, p. 269-281.

Giese, G. S., D. G. Aubrey and J. T. Liu, 1989. Development, characteristics, and effects of the new Chatham Harbor inlet. Woods Hole Occanographic Institution, WHOI-89-19, Woods Hole, MA, 32 pp.

Gicse, G. S., C. T. Fricdrichs, D. G. Aubrey and R. G. Lewis II, 1990. Application and assessment of a shallow-water tide model to Pamet River, Truro, Massachusetts. A report submitted to the Truro Conservation Trust, Truro, MA, $26 \mathrm{pp}$.

Goldsmith, V., 1972. Coastal processes of a barricr island complex and adjacent ocean floor: Monomoy Island-Nauset Spit, Cape Cod, Massachusetts. Ph.D. thesis, University of Massachusetts, Amherst, MA, 469 pp.

Leatherman, S. P., and R. E. Zaremba, 1986. Dynamics of a northern barrier beach: Nauset Spit, Cape Cod, Massachusetts. Geological Society of America Bulletin, v. 97, p. 116124.

Liu, J. T., D. K. Stauble, G. S. Giese and D. G. Aubrey, this volume. Morphodynamic evolution of a newly formed tidal inlet. In: Aubrey, D.G. and G. S. Giese (eds.), Formation and Evolution of Multiple Inlet Systems. Coastal and Estuarine Studies Series, AGU.

McClennen, C. E., 1979. Nausct Spit: model of cyclical breaching and spit regeneration during coastal retreat. In: S. P. Leatherman (cd.), Environmental Geological Guide to Cape Cod National Seashore, S.E.P.M., Eastern Scction Field Trip Guide Book. Boulder, CO., p. 109-118. 
Mitchell, H., 1874. Report to Prof. Benjamin Pierce, Superintendent United States Coast Survey, concerning Nauset Beach and the peninsula of Monomoy. In: Report of the Superintendent of the United States Coast Survey for 1871, Appendix No. 9, p. 134-143.

Ogden, J. G., 1974. Shoreline changes along the Southeastern coast of Martha's Vineyard, Massachusetts for the past 200 years. Quaternary Research, v. 4, p. 496-508.

Oldale, R. N., J. D. Friedman and R. S. Williams Jr., 1971. Changes in coastal morphology of Monomoy Island, Cape Cod, Massachusetts. U.S. Geological Survey Professional Paper, v. 750-B, p. B101-B107.

Speer,P.E., and D. G. Aubrcy, 1985. A study of non-linear tidal propagation in shallow inlet/ estuarine systems, part II: thcory. Estuarine, Coastal and Shelf Science, v. 21, p. 207 224.

U.S. Army Corps of Engineers, 1968. Survey report: Pleasant Bay, Chatham, Orleans, Harwich, Massachusetts. Department of the Army, New England Division, Corps of Engineers, Waltham, MA, 61 p. + appendices.

Weidman, C. R., D. G. Aubrey and C. T. Friedrichs, in prep. Tidal dynamics of the water table in a barrier beach. 